\title{
Highly selective supported gold catalyst for CO-driven reduction of furfural in aqueous media
}

\author{
Jing Dong a,b, Mingming Zhu a, Gaoshuo Zhang a, Yongmei Liu a, Yong Cao a,*, Su Liu b, \\ Yangdong Wang b,\# \\ a Shanghai Key Laboratory of Molecular Catalysis and Innovative Materials, Department of Chemistry, Fudan University, Shanghai 200433, China \\ b SINOPEC Shanghai Research Institute of Petrochemical Technology, Shanghai 201208, China
}

\section{A R T I C L E I N F O}

\section{Article history:}

Accepted 10 May 2016

Published 5 October 2016

\section{Keywords:}

Furfural

Reduction

Supported gold catalyst

Carbon monoxide

Aqueous
Received 14 April 2016

\section{A B S T R A C T}

The reductive transformation of furfural (FAL) into furfuryl alcohol (FOL) is an attractive route for the use of renewable bio-sources but it suffers from the heavy use of $\mathrm{H}_{2}$. We describe here a highly efficient reduction protocol for converting aqueous FAL to FOL. A single phase rutile $\mathrm{TiO}_{2}$ support with a gold catalyst $\left(\mathrm{Au} / \mathrm{TiO}_{2}-\mathrm{R}\right)$ that used $\mathrm{CO} / \mathrm{H}_{2} \mathrm{O}$ as the hydrogen source catalyze this reduction efficiently under mild conditions. By eliminating the consumption of fossil fuel-derived $\mathrm{H}_{2}$, our process has the benefit afforded by using $\mathrm{CO}$ as a convenient and cost competitive reducing reagent.

(C) 2016, Dalian Institute of Chemical Physics, Chinese Academy of Sciences. Published by Elsevier B.V. All rights reserved.

\section{Introduction}

The search for chemical processes to convert biogenic feedstocks to renewable chemicals and fuels has driven efforts to discover and develop new effective reactions that enable the selective refunctionalization of these polyoxygenate materials [1-5]. In this context, furfural (FAL) represents a promising biogenic building block and the direct conversion of FAL into furfuryl alcohol (FOL) by catalytic reduction has been identified as a reliable feedstock source to open new scenarios for sustainable chemical production [6-10]. Historically, the reduction of furfural under an aggressive hydrogen atmosphere has been the focus of extensive efforts. Recent progress has demon- strated the potential of this approach in setting up a biobased economy [11-17]. However, $\mathrm{H}_{2}$ is mainly produced from fossil fuels, which in turn make the process dependent on fossil carbon. Moreover, the necessity of special handling for the highly flammable $\mathrm{H}_{2}$ gas and the requirement of an organic solvent to achieve a high selectivity have diminished the appeal of these procedures [12-15]. Any strategy and conditions that can address these issues will be advantageous not only for FAL reduction but also for the reduction of biomass intermediates such as 5-hydroxymethylfurfural (HMF).

Due to the potential for the use of CO as a key intermediate in the chemical industry, mainly as a $\mathrm{C}_{1}$ building block, there is continuous interest in the development of transformations for

\footnotetext{
* Corresponding author. Tel: +86-21-55665287; Fax: +86-21-65643774; E-mail: yongcao@fudan.edu.cn

\# Corresponding author. Tel: +86-21-68462947; Fax: +86-21-68462283; E-mail: wangyd.sshy@sinopec.com

This work was supported by the National Natural Science Foundation of China $(21273044,21473035,91545108)$, the Research Fund for the Doctoral Program of Higher Education (2012007000011), SINOPEC (X514005), Science \& Technology Commission of Shanghai Municipality (08DZ2270500), and the Open Project of State Key Laboratory of Chemical Engineering (SKL-ChE-15C02).

DOI: 10.1016/S1872-2067(16)62458-0 | http://www.sciencedirect.com/science/journal/18722067 | Chin. J. Catal., Vol. 37, No. 10, October 2016
} 
$\mathrm{CO}$ valorization. The use of $\mathrm{CO}$ instead of hydrogen or other hydrogen donor agents is particularly interesting since CO is currently produced in multi-ton quantities as a byproduct of the steel industry [18] and thus represents an abundant source for chemical reduction $[19,20]$. One conceptually straightforward way is to use a $\mathrm{CO} / \mathrm{H}_{2} \mathrm{O}$ couple as a source of hydrogen, although the most ideal scenario would be $\mathrm{CO}$ as sole reductant without an external hydrogen source [19]. We have contributed to this field by discovering an excellent Au-catalyzed $\mathrm{CO} / \mathrm{H}_{2} \mathrm{O}$-driven strategy that allowed rapid and chemoselective reduction of substituted nitro and carbonyl groups under very mild conditions $[20,21]$. Our subsequent studies revealed that the Au-CO-assisted reduction strategy could be used for reductive imination and carbonylative alkyne semireduction [22,23].

Our continuing interest in the development of innovative CO-based catalytic reduction technologies led us to investigate the reduction efficiency of the $\mathrm{Au}-\mathrm{CO} / \mathrm{H}_{2} \mathrm{O}$ protocol for the transformation of biogenic platform chemicals [24]. We disclose here the versatile catalytic behavior of supported Au nanoparticles (NPs) in the reductive transformation of FAL to FOL without the use of $\mathrm{H}_{2}$. We demonstrate that adopting a suitable inorganic support such as single phase rutile $\mathrm{TiO}_{2}$ to anchor finely dispersed Au NPs enabled a highly selective and efficient transformation of FAL to FOL in water under a mild CO atmosphere (Scheme 1). As opposed to previous procedures, this $\mathrm{Au}-\mathrm{CO} / \mathrm{H}_{2} \mathrm{O}$-mediated reduction system can deliver high selectivity in the reduction of aqueous FAL, affording exclusively the corresponding FOL in a mild, economical and green manner. This reduction using a simple and robust gold catalyst coupled with $\mathrm{CO} / \mathrm{H}_{2} \mathrm{O}$ as the hydrogen source under mild conditions can make a significant contribution to the catalytic potential of supported Au NPs and to establish an approach for more efficient FAL reduction.

\section{Experimental}

\subsection{Preparation}

Anatase $\left(\mathrm{TiO}_{2}-\mathrm{A}\right.$, surface area of $\left.154 \mathrm{~m}^{2} / \mathrm{g}\right)$, rutile $\left(\mathrm{TiO}_{2}-\mathrm{R}\right.$, surface area of $\left.65 \mathrm{~m}^{2} / \mathrm{g}\right), \mathrm{Au} / \mathrm{ZrO}_{2}\left(\mathrm{ZrO}_{2}\right.$, surface area of 115 $\mathrm{m}^{2} / \mathrm{g}$ ), $\mathrm{Au} / \mathrm{TiO}_{2}$ (P25, surface area of $45 \mathrm{~m}^{2} / \mathrm{g}$; P90, surface area of $\left.95 \mathrm{~m}^{2} / \mathrm{g}\right), \mathrm{Au} / \mathrm{CeO}_{2}\left(\mathrm{CeO}_{2}\right.$, surface area of $\left.139 \mathrm{~m}^{2} / \mathrm{g}\right)$ and $\mathrm{Au} / \mathrm{HT}$ (HT, surface area of $118 \mathrm{~m}^{2} / \mathrm{g}$ ). All the supports and catalysts were prepared by using previously described methods [23-30].

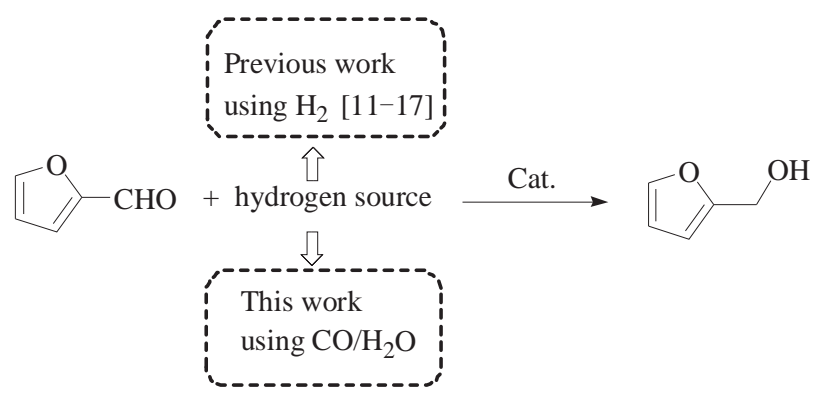

Scheme 1. Reductive transformation of FAL to FOL with various hydrogen sources.
The $0.6 \mathrm{wt} \% \mathrm{Au} / \mathrm{TiO}_{2}-\mathrm{R}$ sample was prepared by a routine deposition-precipitation (DP) method [30,31]. In brief, an aqueous solution of $\mathrm{HAuCl}_{4}$ was added to $100 \mathrm{~mL}$ of deionized water at $80{ }^{\circ} \mathrm{C}$ under vigorous stirring. The $\mathrm{pH}$ was adjusted to 7.0 and $1.0 \mathrm{~g} \mathrm{TiO}_{2}-\mathrm{R}$ was dispersed in the solution with the $\mathrm{pH}$ kept constant at 6.5-7.0. The mixture was stirred for $2 \mathrm{~h}$ at 80 ${ }^{\circ} \mathrm{C}$. After that, the suspension was cooled to $25{ }^{\circ} \mathrm{C}$. After thorough washing with deionised water, the samples were dried under vacuum at $25{ }^{\circ} \mathrm{C}$ for $12 \mathrm{~h}$ and then calcined in a muffle oven at $350{ }^{\circ} \mathrm{C}$ for 2 h. 0.6 wt $\%$ Au/ $/ \mathrm{TiO}_{2}-\mathrm{A}, 0.6 \mathrm{wt} \%$ $\mathrm{Au} / \mathrm{TiO}_{2}-\mathrm{P} 25$, and $0.6 \mathrm{wt} \% \mathrm{Au} / \mathrm{TiO}_{2}-\mathrm{P} 90$ were prepared by the same method.

0.6 wt $\% \mathrm{Ir} / \mathrm{TiO}_{2}-\mathrm{R}, 0.6$ wt $\% \mathrm{Pd} / \mathrm{TiO}_{2}-\mathrm{R}, 0.6 \mathrm{wt} \% \mathrm{Pt} / \mathrm{TiO}_{2}-\mathrm{R}$, $0.6 \mathrm{wt} \% \mathrm{Ru} / \mathrm{TiO}_{2}-\mathrm{R}$ catalysts were prepared by incipient wetness impregnation (IWI) of the support with aqueous solutions of $\mathrm{H}_{2} \mathrm{IrCl}_{6} \cdot 6 \mathrm{H}_{2} \mathrm{O}, \mathrm{PdCl}_{2}, \mathrm{H}_{2} \mathrm{PtCl}_{6} \cdot 6 \mathrm{H}_{2} \mathrm{O}$ or $\mathrm{RuCl}_{3}$ precursors, respectively [31]. After mixing the corresponding slurries, the mixture was vigorously stirred at $80^{\circ} \mathrm{C}$ for $4 \mathrm{~h}$. Then samples were dried under vacuum at $25^{\circ} \mathrm{C}$ for $12 \mathrm{~h}$ and then reduced in 5 vol\% $\mathrm{H}_{2} / \mathrm{Ar}(80 \mathrm{~mL} / \mathrm{min})$ at $400{ }^{\circ} \mathrm{C}$ for $2 \mathrm{~h}$.

\subsection{Characterization}

X-ray diffraction (XRD) analysis was carried out on a German Bruker D8Advance X-ray diffractometer using nickel filtered $\mathrm{Cu} \mathrm{K} \alpha$ radiation with a scanning angle $(2 \theta)$ of $10^{\circ}-80^{\circ}$, a scanning speed of $2^{\circ} / \mathrm{min}$, and a voltage and current of $40 \mathrm{kV}$ and $20 \mathrm{~mA}$. Transmission electron microscope (TEM) images were taken with a JEOL 2011 electron microscope operating at $200 \mathrm{kV}$. Before being transferred into the TEM chamber, the samples were dispersed in ethanol and deposited onto a carbon-coated copper grid and then quickly moved into the vacuum evaporator. The size distribution of the metal particles was determined by measuring about 200 random particles in the images. CO temperature programmed reduction (CO-TPR) experiments were carried out on a homemade apparatus described elsewhere [32]. X-ray photoelectron spectroscopy (XPS) analysis was performed using a Perkin Elmer PHI 5000C system equipped with a hemispherical electron energy analyzer. The $\operatorname{Mg} K_{\alpha}(h v=1253.6 \mathrm{eV})$ was operated at $15 \mathrm{kV}$ and 20 $\mathrm{mA}$. The energy scale was internally calibrated by setting the $\mathrm{C}$ 1 s peak at $284.6 \mathrm{eV}$. The solution after reaction was measured by inductively coupled plasma atomic emission spectroscopy (ICP-AES) using a Thermo Electron IRIS Intrepid II XSP spectrometer.

\subsection{Reduction of FAL to FOL}

A 25-mL Hastelloy-C high pressure Parr reactor was used to carry out the liquid phase reduction reaction. A mixture of FAL (2.6 mmol, fresh distilled), supported metal catalysts, water (20 $\mathrm{mL}$ ) were loaded into the reactor. The reactor was stirred at a rate of $800 \mathrm{r} / \mathrm{min}$ under $4 \mathrm{MPa} \mathrm{CO}$ (syngas, or $\mathrm{H}_{2}$ ) for a specific reaction time at a given temperature. After reaction, the $\mathrm{CO}$ atmosphere was removed and the resultant product mixture was transferred with $5 \mathrm{~mL}$ of ethanol. An amount of $\mathrm{N}, \mathrm{N}$-dimethylformamide (DMF) was then added as an internal 
standard substance. The samples were analyzed on a Agilent GC-6820 gas chromatograph equipped with a capillary column DB-Wax (30 $\mathrm{m} \times 0.25 \mathrm{~mm})$ and FID detector. The identification of the products was performed by using a GC-MS spectrometer.

\section{Results and discussion}

At first, the reaction was evaluated using a diluted aqueous solution of freshly distilled FAL $(0.13 \mathrm{~mol} / \mathrm{L})$ and Au NPs (average diameter of ca. $2.2 \mathrm{~nm}$ ) deposited on some common inorganic oxides with a substrate-to-gold $\left(n_{\mathrm{FAL}} / n_{\mathrm{Au}}\right)$ ratio of 200:1 under mild conditions (4 MPa of CO pressure in neat water at $90^{\circ} \mathrm{C}$ ). We initially focused our attention on $\mathrm{Au} / \mathrm{CeO}_{2}$ because of the successful application of this Au-based catalyst for the chemoselective reduction of a range of a, $\beta$-unsaturated aldehydes, e.g., crotonaldehyde and cinnamaldehyde, to their allyl alcohols in the presence of $\mathrm{CO}$ and $\mathrm{H}_{2} \mathrm{O}$ [21]. However, this material afforded only modest activity for the $\mathrm{CO} / \mathrm{H}_{2} \mathrm{O}$-mediated FAL to FOL reduction under the screening conditions employed (Table 1, entry 1). We then turned our attention to the selection of other commonly used Au-support combinations that have proven effective in the $\mathrm{Au}-\mathrm{CO} / \mathrm{H}_{2} \mathrm{O}$-mediated reductive transformation, including $\mathrm{Au} / \mathrm{TiO}_{2}-\mathrm{P} 25, \mathrm{Au} / \mathrm{Al}_{2} \mathrm{O}_{3}, \mathrm{Au} / \mathrm{ZrO}_{2}$ and $\mathrm{Au} / \mathrm{Mg}$-Al hydrotalcite (Table 1, entries 2-5). While none were found to be particularly active for FAL reduction, the modest success achieved with $\mathrm{Au} / \mathrm{TiO}_{2}-\mathrm{P} 25$ prompted a more detailed survey of structurally related $\mathrm{Au}-\mathrm{TiO}_{2}$-based systems.

We subsequently optimized the $\mathrm{Au}-\mathrm{TiO}_{2}$ catalysts by alter-

Table 1

FAL conversion and FOL selectivity with different catalysts.

\begin{tabular}{|c|c|c|c|c|c|c|}
\hline Entry & Catalyst & $\begin{array}{c}p \\
(\mathrm{MPa})\end{array}$ & $\begin{array}{c}T \\
\left({ }^{\circ} \mathrm{C}\right) \\
\end{array}$ & $\begin{array}{c}t \\
(\mathrm{~h}) \\
\end{array}$ & $\begin{array}{c}\text { Conversion }^{\text {a }} \\
(\%)\end{array}$ & $\begin{array}{c}\text { Selectivity }^{\mathrm{a}} \\
(\%)\end{array}$ \\
\hline 1 & $\mathrm{Au} / \mathrm{CeO}_{2}$ & 4 & 90 & 2 & 21 & 100 \\
\hline 2 & $\mathrm{Au} / \mathrm{TiO}_{2}-\mathrm{P} 25$ & 4 & 90 & 2 & 53 & 100 \\
\hline 3 & $\mathrm{Au} / \mathrm{ZrO}_{2}$ & 4 & 90 & 2 & 15 & 100 \\
\hline 4 & $\mathrm{Au} / \mathrm{Al}_{2} \mathrm{O}_{3}$ & 4 & 90 & 2 & 1 & 100 \\
\hline 5 & $\mathrm{Au} / \mathrm{HT}$ & 4 & 90 & 2 & 18 & 100 \\
\hline 6 & $\mathrm{Au} / \mathrm{TiO}_{2}-\mathrm{P} 90$ & 4 & 90 & 2 & 52 & 100 \\
\hline 7 & $\mathrm{Au} / \mathrm{TiO}_{2}-\mathrm{R}$ & 4 & 90 & 2 & 67 & 100 \\
\hline 8 & $\mathrm{Au} / \mathrm{TiO}_{2}-\mathrm{A}$ & 4 & 90 & 2 & 48 & 100 \\
\hline 9 & $\mathrm{Au} / \mathrm{TiO}_{2}-\mathrm{R}$ & 4 & 90 & 4 & 100 & 100 \\
\hline 10 & $\mathrm{Au} / \mathrm{TiO}_{2}-\mathrm{R}$ & 2 & 90 & 7 & 100 & 100 \\
\hline 11 & $\mathrm{Au} / \mathrm{TiO}_{2}-\mathrm{R}$ & 6 & 90 & 2.5 & 100 & 100 \\
\hline 12 & $\mathrm{Au} / \mathrm{TiO}_{2}-\mathrm{R}$ & 4 & 120 & 2 & 100 & 100 \\
\hline 13 & $\mathrm{Au} / \mathrm{TiO}_{2}-\mathrm{R}$ & 4 & 30 & 4 & 19 & 100 \\
\hline $14^{b}$ & $\mathrm{Au} / \mathrm{TiO}_{2}-\mathrm{R}$ & 4 & 90 & 23 & 100 & 100 \\
\hline $15^{c}$ & $\mathrm{Au} / \mathrm{TiO}_{2}-\mathrm{R}$ & 4 & 90 & 61 & 99 & 100 \\
\hline $16^{d}$ & $\mathrm{Au} / \mathrm{TiO}_{2}-\mathrm{R}$ & 4 & 90 & 4.5 & 100 & 100 \\
\hline 17 & $\mathrm{Ir} / \mathrm{TiO}_{2}-\mathrm{R}$ & 4 & 90 & 4 & 8 & 100 \\
\hline 18 & $\mathrm{Pd} / \mathrm{TiO}_{2}-\mathrm{R}$ & 4 & 90 & 4 & 1 & 100 \\
\hline 19 & $\mathrm{Pt} / \mathrm{TiO}_{2}-\mathrm{R}$ & 4 & 90 & 4 & 1 & 100 \\
\hline 20 & $\mathrm{Ru} / \mathrm{TiO}_{2}-\mathrm{R}$ & 4 & 90 & 4 & 1 & 100 \\
\hline $21 \mathrm{e}$ & $\mathrm{Au} / \mathrm{TiO}_{2}-\mathrm{R}$ & 4 & 90 & 4 & 100 & 100 \\
\hline
\end{tabular}

Reaction conditions: FAL $2.6 \mathrm{mmol}$, water $20 \mathrm{~mL}, n_{\mathrm{FAL}} / n_{\mathrm{Au}}=200,90^{\circ} \mathrm{C}$, $p(\mathrm{CO})=4 \mathrm{MPa}, 2 \mathrm{~h}$.

a Conversion and selectivity were determined by GC and GC-MS with

$\mathrm{N}, \mathrm{N}$-dimethylformamide as the internal standard.

${ }^{\mathrm{b}} n_{\mathrm{FAL}} / n_{\mathrm{Au}}=2000$.

${ }^{\mathrm{c}} n_{\mathrm{FAL}} / n_{\mathrm{Au}}=5000$.

$\mathrm{d}$ The $5^{\text {th }}$ reuse of the catalyst recovered from entry 10 .

e Using aged distillates of FAL as feedstock.

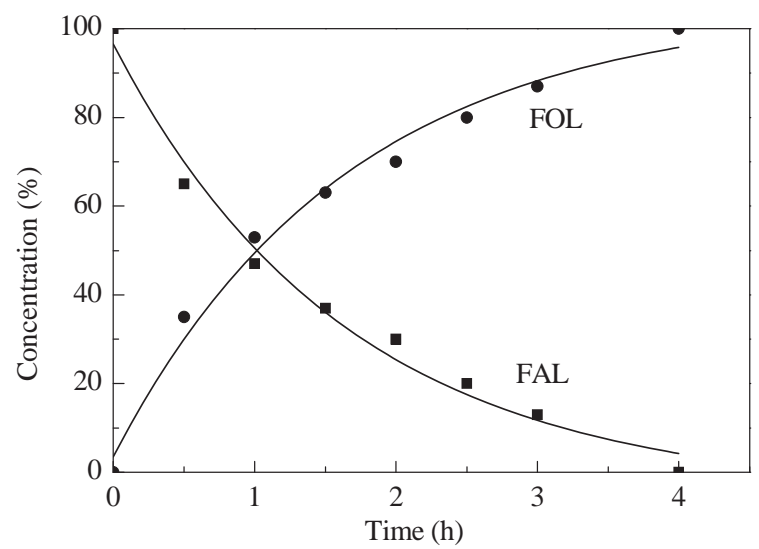

Fig. 1. Time profiles of FAL reduction over $\mathrm{Au} / \mathrm{TiO}_{2}-\mathrm{R}$. Reaction conditions: FAL $2.6 \mathrm{mmol}$, water $20 \mathrm{~mL}, n_{\mathrm{FAL}} / n_{\mathrm{Au}}=200,90^{\circ} \mathrm{C}, p(\mathrm{CO})=4 \mathrm{MPa}$.

ing the $\mathrm{TiO}_{2}$ phase during the preparation (Table 1 , entry 1 , 6-8). Eventually, the optimized $\mathrm{Au} / \mathrm{TiO}_{2}-\mathrm{R}$ comprising gold deposited on single phase rutile $\mathrm{TiO}_{2}\left(\mathrm{Au} / \mathrm{TiO}_{2}-\mathrm{R}\right)$ was the most efficient, which accomplished quantitative FAL-to-FOL conversion within only $4 \mathrm{~h}$ at $90{ }^{\circ} \mathrm{C}$ (Table 1 , entry 9). A plot of the time dependent conversion of FAL (Fig. 1) revealed that the reaction proceeded smoothly and FOL was the only product, that is, we did not detect any other product during the whole reaction. Furthermore, in a series of studies examining the effect of pressure, the reaction time was shortened from 4 to 2.5 $\mathrm{h}$ as the $p_{\text {co }}$ was raised from 4 to $6 \mathrm{MPa}$ (Table 1, entries 9 and 11). Further experiments on the effect of temperature indicated that the $\mathrm{Au} / \mathrm{TiO}_{2}-\mathrm{R}$ catalyst exhibited rather low activity at 30 ${ }^{\circ} \mathrm{C}$ (Table 1, entry 13). At $120^{\circ} \mathrm{C}$, quantitative formation of FOL was attained at $4 \mathrm{MPa}$ within $2 \mathrm{~h}$ (Table 1 , entry 12 ).

In line with several other $\mathrm{CO} / \mathrm{H}_{2} \mathrm{O}$-mediated reduction [20-23], we found that $\mathrm{Au}$ was as active for the reduction of FAL with $\mathrm{CO} / \mathrm{H}_{2} \mathrm{O}$ as traditional noble metals (Table 1, entries 17-20). These results confirmed that the combination of $\mathrm{Au}$ NPs with a suitable $\mathrm{TiO}_{2}$ phase could achieve a high catalytic activity for the selective reduction of FAL into FOL. After the

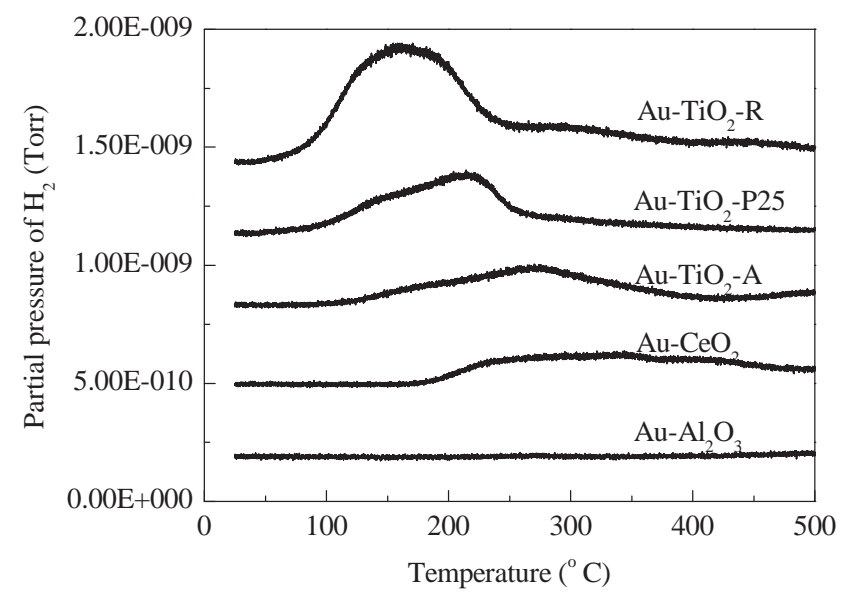

Fig. 2. CO TPR profiles $(1 \% \mathrm{CO}$ in $\mathrm{He}, 20 \mathrm{~mL} / \mathrm{min}$; heating rate: 5 ${ }^{\circ} \mathrm{C} / \mathrm{min}$; $100 \mathrm{mg}$ sample) for different Au catalysts. Each sample was purged with $20 \mathrm{~mL} / \mathrm{min} \mathrm{He}$ at $100{ }^{\circ} \mathrm{C}$ for $30 \mathrm{~min}$ and then cooled to 30 ${ }^{\circ} \mathrm{C}$ in He. Before being heated from 30 to $550{ }^{\circ} \mathrm{C}$, the sample was stabilized in 1\% CO in He for $30 \mathrm{~min}$. 
reduction of $\mathrm{FAL}, \mathrm{Au} / \mathrm{TiO}_{2}-\mathrm{R}$ can be separated from the reaction mixture and reused without loss of catalytic efficiency (Table 1, entries 16). To gain insight into the origin of the enhanced $\mathrm{CO} / \mathrm{H}_{2} \mathrm{O}$-mediated reduction activity achieved by using rutile $\mathrm{TiO}_{2}$ as the support, CO-TPR was performed for Au deposited on different supports (Fig. 2). This revealed that the lower performance observed with $\mathrm{Au} / \mathrm{TiO}_{2}-\mathrm{A}, \mathrm{Au} / \mathrm{Al}_{2} \mathrm{O}_{3}$ and $\mathrm{Au} / \mathrm{CeO}_{2}$ were due to that the $\mathrm{H}_{2}$ formation rates catalyzed by these catalysts were significantly lower than that over the $\mathrm{Au} / \mathrm{TiO}_{2}-\mathrm{R}$ sample. This was reinforced by the observation that the low temperature $\mathrm{H}_{2}$ production rate over $\mathrm{Au} / \mathrm{TiO}_{2}-\mathrm{R}$ also occurred at a much higher rate than that over $\mathrm{TiO}_{2}-\mathrm{P} 25$ supported $\mathrm{Au}$. Taken together, these results demonstrated that the Au-catalyzed $\mathrm{CO} / \mathrm{H}_{2} \mathrm{O}$-mediated $\mathrm{FAL}$ reduction proceeded by a sequential water-gas-shift/FAL-reduction pathway (Scheme 2), in which the generation of a transient $\mathrm{Au}^{0}-\mathrm{H}$ species formed by CO-induced $\mathrm{H}_{2} \mathrm{O}$ activation was the main step.

These results showed that the $\mathrm{Au} /$ rutile-based catalyst facilitated efficient FAL-to-FOL conversion without an external $\mathrm{H}_{2}$ supply. By investigating the physicochemical properties of the $\mathrm{Au} / \mathrm{TiO}_{2}-\mathrm{R}$ catalyst, the following information was collected. From the XPS results, it was seen that there was only metallic $\mathrm{Au}$ on the $\mathrm{Au} /$ rutile sample (Fig. 3(a)). ICP-AES data revealed that there was no Au species in the solution after the reaction, which indicated the absence of Au leaching during the reaction. XRD analysis displayed that both the fresh and used $\mathrm{Au} / \mathrm{TiO}_{2}-\mathrm{R}$ catalysts showed the same crystal phase, with no obvious $\mathrm{Au}$ feature being identified in these two samples, which suggested that the particle sizes of Au were quite small (Fig. 3(b)). TEM

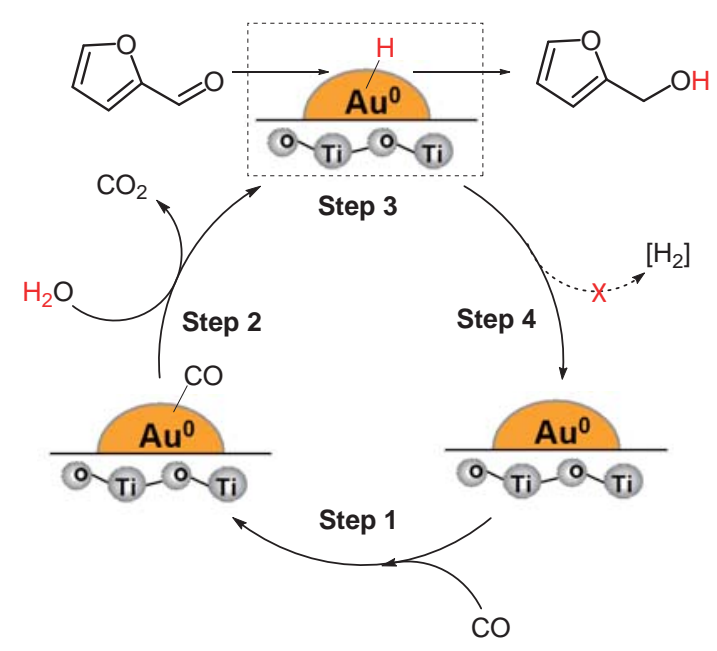

Scheme 2. Mechanism for the $\mathrm{Au} / \mathrm{TiO}_{2}$-R-catalyzed reduction of $\mathrm{HMF}$ by $\mathrm{CO} / \mathrm{H}_{2} \mathrm{O}$.

confirmed that the average diameter of the Au particles was 2.2 $\mathrm{nm}$ in the fresh and used $\mathrm{Au} / \mathrm{TiO}_{2}$ - $\mathrm{R}$ catalysts, verifying there was no Au NPs aggregation during the reaction (Fig. 3(c) and (d)). These results accounted for the remarkable stability of $\mathrm{Au} / \mathrm{TiO}_{2}-\mathrm{R}$ in the recycling tests.

As a further illustration of the effectiveness of the above reduction, full conversion of FAL was readily obtained at a $n_{\mathrm{FAL}} / n_{\mathrm{Au}}$ ratio of 2000 (Table 1, entry 14). This $\mathrm{Au}-\mathrm{CO} / \mathrm{H}_{2} \mathrm{O}$-mediated reduction still occurred with only 0.02 mol\% of the $\mathrm{Au} / \mathrm{TiO}_{2}-\mathrm{R}$, albeit an extended reaction time of 61
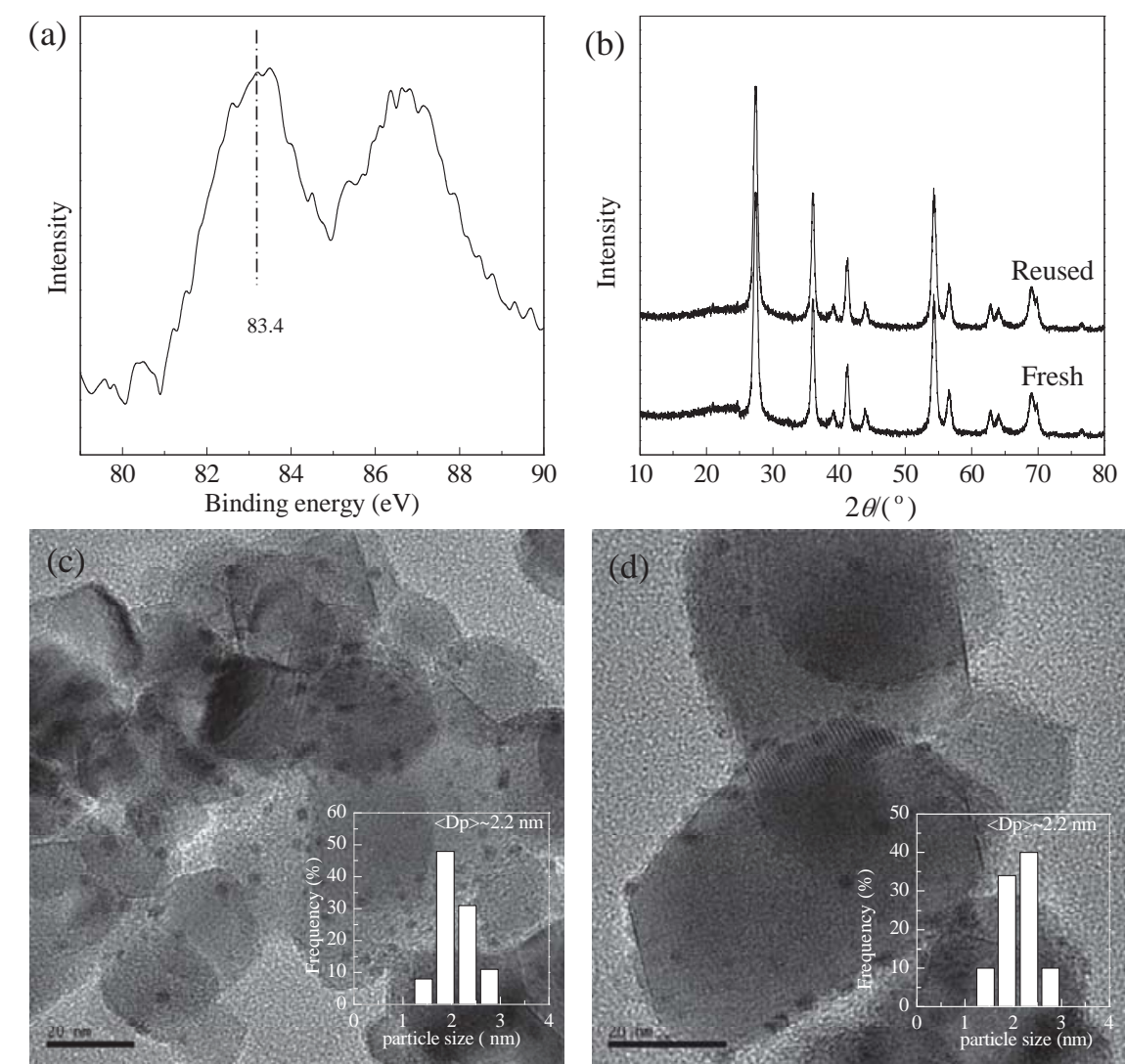

Fig. 3. (a) XPS spectrum of $\mathrm{Au} / \mathrm{TiO}_{2}-\mathrm{R}$; (b) XRD patterns of fresh and used $\mathrm{Au} / \mathrm{TiO}_{2}-\mathrm{R}$; $\mathrm{TEM}$ images of fresh (c) and used (d) $\mathrm{Au} / \mathrm{TiO}_{2}-\mathrm{R}$. 


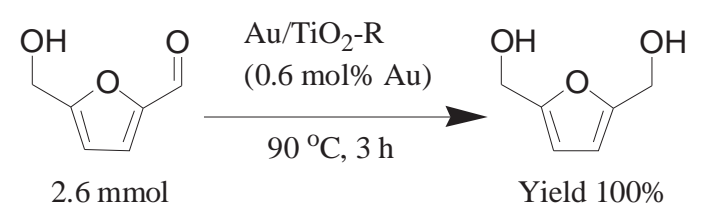

Scheme 3. Reduction of $\mathrm{HMF}$ by $\mathrm{CO} / \mathrm{H}_{2} \mathrm{O}$.

$\mathrm{h}$ was required (Table 1 , entry 15). Under these conditions, remarkable values of the turnover number $($ TON $=5000)$ and average turnover frequency (TOF $=91 \mathrm{~h}^{-1}$ ) were calculated (Table 1, entry 15). Perhaps the most notable finding was the ability of the $\mathrm{Au}-\mathrm{CO} / \mathrm{H}_{2} \mathrm{O}$-based protocol to convert aged distillates of FAL to value added material. Along these lines, we demonstrated that the present Au-based technology could be used to convert FAL that was set aside for more than a month into FOL with high efficiency (Table 1, entry 21). These results were extremely encouraging because they showed that crude FOL could be used directly as a feedstock for industrially relevant transformations [33,34]. Furthermore, this $\mathrm{Au}-\mathrm{CO} / \mathrm{H}_{2} \mathrm{O}$ mediated reduction process was not limited to FAL. When $\mathrm{HMF}$, another key intermediate in biomass conversion, was subjected to the reduction in the presence of the $\mathrm{Au} / \mathrm{TiO}_{2}-\mathrm{R}$ sample, the reaction also proceeded efficiently. In this case, 2 , 5-bis-(hydroxymethyl) furan (BHMF), an important monomer for industrial processes, was exclusively obtained under the standard reaction conditions (Scheme 3).

Given the fact that producing $\mathrm{CO}$ and $\mathrm{H}_{2}$ (syngas) from biomass is a crucial step in the production of most second generation biofuels, we explored the possibility to produce FOL by aqueous FAL reduction using simulated syngas with a varying $\mathrm{H}_{2} / \mathrm{CO}$ feed ratio. Three different volumetric compositions of syngas were examined. As shown in Table 2, in all cases, FAL was quantitatively converted into FOL but different reaction times were required. The reaction involving the $\mathrm{H}_{2}$-rich syngas proceeded much more rapidly than the reaction with the CO-rich syngas. This was in agreement with that the reaction proceeded at a much faster rate with $\mathrm{H}_{2}$ as the sole reductant. More important, this revealed that cheap, renewable and easily accessible $\mathrm{CO}_{2}$-rich bio-syngas could be successfully used for FAL reduction. These results are particularly relevant since flexible and versatile syngas can be used as a direct hydrogen source for selective biomass conversion. This would open the possibility to develop cost effective technologies for the production of bio-renewable chemicals based on CO-driven reduction.

\section{Table 2}

FAL reduction using syngas with varying $\mathrm{H}_{2} / \mathrm{CO}$ feed ratio as hydrogen source.

\begin{tabular}{lccc}
\hline $\mathrm{H}_{2} / \mathrm{CO}$ & Time $(\mathrm{h})$ & Conversion $(\%)$ & Selectivity (\%) \\
\hline $1: 1$ & 2.5 & 100 & 100 \\
$2: 1$ & 1.8 & 100 & 100 \\
bio-syngas * & 2 & 100 & 100 \\
pure $\mathrm{H}_{2}$ & 1 & 100 & 100
\end{tabular}

Reaction condition: FAL $2.6 \mathrm{mmol}$, water $20 \mathrm{~mL}, \mathrm{Au} / \mathrm{TiO}_{2}-\mathrm{R}, n_{\mathrm{FAL}} / n_{\mathrm{Au}}=$ $200,90^{\circ} \mathrm{C}, p(\mathrm{CO})=4 \mathrm{MPa}$.

${ }^{*} \mathrm{H}_{2}: \mathrm{CO}: \mathrm{CO}_{2}=10: 5: 1$.

\section{Conclusions}

$\mathrm{TiO}_{2}$ supported $\mathrm{Au}$ catalysts, in particular the $\mathrm{Au} / \mathrm{TiO}_{2}-\mathrm{R}$ system, were very promising for the selective reduction of bio-derived furfural using $\mathrm{CO}$ as a convenient and cost competitive hydrogen source. This Au-based catalytic protocol constitutes the first furfural reduction system that directly used syngas as a hydrogen source and would furnish a new application of syngas. As controlled hydrogenation and reductive transformation is a very general issue in the conversion of bio-derived feedstocks, the procedure here is expected to be of broad applicability in the utilization of biomass.

\section{References}

[1] G. W. Huber, S. Iborra, A. Corma, Chem. Rev., 2006, 106, 4044-4098.

[2] A. Corma, S. Iborra, A. Velty, Chem. Rev., 2007, 107, 2411-2502.

[3] J. A. Melero, J. Iglesias, A. Garcia, Energy Environ. Sci., 2012, 5, 7393-7420.

[4] J. C. Serrano-Ruiz, R. Luque, A. Sepulveda-Escribano, Chem. Soc. Rev., 2011, 40, 5266-5281.

[5] P. Gallezot, Chem. Soc. Rev., 2012, 41, 1538-1558.

[6] J. P. Lange, E. van der Heide, J. van Buijtenen, R. Price, ChemSusChem, 2012, 5, 150-166.

[7] C. M. Cai, T. Y. Zhang, R. Kumara, C. E. Wyman, J. Chem. Technol. Biotechnol., 2014, 89, 2-10.

[8] R. Karinen, K. Vilonen, M. Niemelä, ChemSusChem, 2011, 4, 1002-1016.

[9] Y. Nakagawa, M. Tamura, K. Tomishige, ACS Catal., 2013, 3, 2655-2668.

[10] B. Danon, G. Marcotullio, W. de Jong, Green Chem., 2014, 16, 39-54.

[11] K. Fulajtárova, T. Soták, M. Hronec, I. Vávra, E. Dobročka, M. Omastová, Appl. Catal. A, 2015, 502, 78-85.

[12] A. B. Merlo, V. Vetere, J. F. Ruggera, M. L. Casella, Catal. Commun., 2009, 10, 1665-1669.

[13] R. V. Sharma, U. Das, R. Sammynaiken, A. K. Dalai, Appl. Catal. A, 2013, 454, 127-136.

[14] M. M. Villaverde, N. M. Bertero, T. F. Garetto, A. J. Marchi, Catal. Today, 2013, 213, 87-92.

[15] M. M. Villaverde, T. F. Garetto, A. J. Marchi, Catal. Commun., 2015, $58,6-10$.

[16] A. Mandalika, L. Qin, T. K. Satob, T. Runge, Green Chem., 2014, 16, 2480-2489.

[17] S. Bhogeswararao, D. Srinivas, J. Catal., 2015, 327, 65-77.

[18] B. P. Bhardwaj, Steel and Iron Handbook, NPCS, Delhi, 2014, 352-356.

[19] H. Q. Li, X. Liu, Q. Zhang, S. S. Li, Y. M. Liu, H. Y. He, Y. Cao, Chem. Commun., 2015, 51, 11217-11220.

[20] L. He, L. C. Wang, H. Sun, J. Ni, Y. Cao, H. Y. He, K. N. Fan, Angew. Chem. Int. Ed., 2009, 48, 9538 -9541.

[21] L. He, F. J. Yu, X. B. Lou, Y. Cao, H. Y. He, K. N. Fan, Chem. Commun., 2010, 46, 1553-1555.

[22] J. Huang, L. Yu, L. He, Y. M. Liu, Y. Cao, K. N. Fan, Green Chem., 2011, 13, 2672-2677.

[23] S. S. Li, X. Liu, Y. M. Liu, H. Y. He, K. N. Fan, Y. Cao, Chem. Commun., 2014, 50, 5626-5628.

[24] L.Yu, X. L. Du, J. Yuan, Y. M. Liu, Y. Cao, H. Y. He, K. N. Fan, ChemSusChem, 2013, 6, 42-46.

[25] X. Liu, H. Q. Li, S. Ye, Y. M. Liu, H. Y. He, Y. Cao, K. N. Fan, Angew. Chem. Int. Ed., 2014, 53, 7624-7629. 


\title{
Graphical Abstract
}

Chin. J. Catal., 2016, 37: 1669-1675 doi: 10.1016/S1872-2067(16)62458-0

Highly selective supported gold catalyst for $\mathrm{CO}$-driven reduction of furfural in aqueous media

Jing Dong, Mingming Zhu, Gaoshuo Zhang, Yongmei Liu, Yong Cao *, Su Liu, Yangdong Wang*

Fudan University; SINOPEC Shanghai Research Institute of Petrochemical Technology

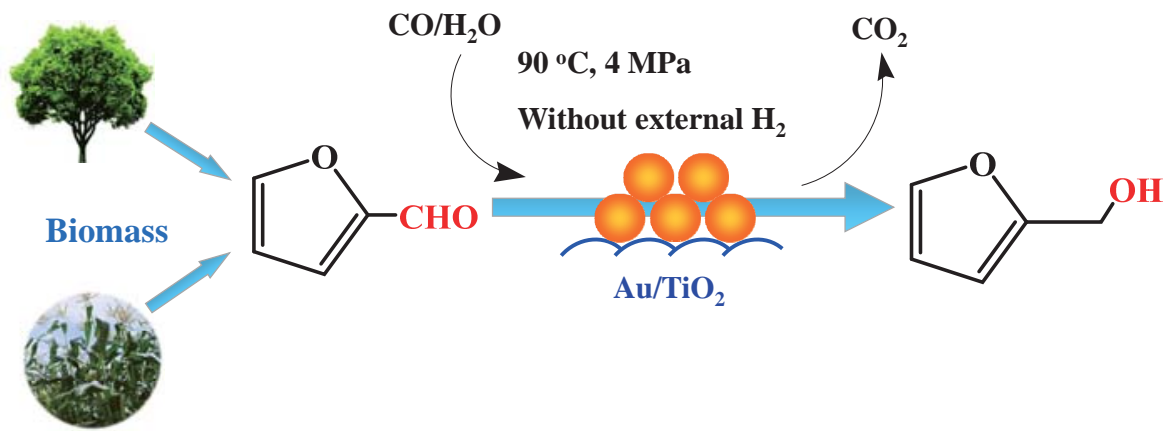

By using a single phase rutile titania support and gold as the catalyst $\left(\mathrm{Au} / \mathrm{TiO}_{2}-\mathrm{R}\right)$, $\mathrm{CO}$ was used as hydrogen source to get furfuryl alcohol as the only product from furfural in aqueous media.

[26] M. M. Wang, L. He, Y. M. Liu, Y. Cao, H. Y. He, K. N. Fan, Green Chem., 2011, 13, 602-607.

[27] X. L. Du, L. He, S. Zhao, Y. M. Liu, Y. Cao, H. Y. He, K. N. Fan, Angew. Chem. Int. Ed., 2011, 50, 7815-7819.

[28] L. Tao, Q. Zhang, S. S. Li, X. Liu, Y. M. Liu, Y. Cao, Adv. Synth. Catal., 2015, 357, 753-760.

[29] L. J. Liu, H. L. Zhao, J. M. Andino, Y. Li, ACS Catal., 2012, 2, 1817-1828.
[30] Q. Y. Bi, X. L. Du, Y. M. Liu, Y. Cao, H. Y. He, K. N. Fan, J. Am. Chem. Soc., 2012, 134, 8926-8933.

[31] L. Yu, Q. Zhang, S. S. Li, J. Huang, Y. M. Liu, H. Y. He, Y. Cao, ChemSusChem, 2015, 8, 3029-3035.

[32] L. C. Wang, X. S. Huang, Q. Liu, Y. M. Liu, Y. Cao, H. Y. He, K. N. Fan, J. H. Zhuang, J Catal., 2008, 259, 66-74.

[33] K. J. Zeitsch. Sugar. Ser., 2000, 13, 75-85.

[34] K. J. Zeitsch. Sugar. Ser., 2000, 13, 28-33.

\section{水相介质中负载纳米金催化 CO 高选择性还原糠醛}

\author{
董 静 ${ }^{\mathrm{a}, \mathrm{b}}$, 朱明明 ${ }^{\mathrm{a}}$, 张高硕 ${ }^{\mathrm{a}}$, 刘永梅 ${ }^{\mathrm{a}}$, 曹 勇 ${ }^{\mathrm{a}, *}$, 刘 苏, 王仰东 ${ }^{\mathrm{b}, \#}$ \\ a复旦大学化学系, 上海市分子催化和功能材料重点实验室, 上海 200433 \\ b中国石油化工股份有限公司上海石油化工研究院, 上海 201208
}

摘要: 近年来可再生资源以及化工原料的多元化备受关注, 生物资源成为其中的一个新亮点. 糠醛是一种可由生物质转化 而来的重要化工原料, 将其催化还原直接转化为糠醇是构建以糠醛为平台化合物的生物基呋喃衍生物价值链的重要环节. 长久以来, 糠醛制糠醇研究主要集中在以 $\mathrm{H}_{2}$ 作氢源的加氢工艺及相关催化剂配方的优化、改进等方面, 尽管在工业上已获 得成功应用, 但由于需大量消耗源于化石燃料的 $\mathrm{H}_{2}$, 使得该路线总体上仍依赖于化石能源. 此外, 大量使用 $\mathrm{H}_{2}$ 所涉及的储 存、运输和使用条件苛刻以及如何有效控制目标产物的选择性等问题也一直是糠醛传统催化加氢所面临的挑战. 因此, 寻 求可替代传统氢气作氢源, 更为经济实用且高效的糠醛高选择性催化还原制糠醇路线, 对于发展以糠醛转化为技术核心的 新一代糠醛基化工产业链, 以及实现诸如 5-差甲基糠醛等其它重要生物质基平台化合物的还原转化, 均具有重要意义.

本文旨在通过实证性实验, 考察以价廉且来源丰富的 $\mathrm{CO}$ 替代 $\mathrm{H}_{2}$ 来实现高选择性液相糠醛催化转化制糠醇的可行性. 众所周知, $\mathrm{CO}$ 不但是 $\mathrm{C}_{1}$ 化学工业中至关重要的基础原料, 在发展并完善面向未来的低碳能源及化学品清洁合成新技术等 方面也有着非常大的应用潜力. 鉴于 CO 也是炼钢焦炉气的重要组成部分, 因此开发新颖的基于 CO 的还原转化和相关反 应新技术, 不但可有效拓展 CO 的潜在应用范围, 对于实现传统高能耗行业的节能减排和转型升级也有着重要的启示和借 鉴意义. 我们近期利用 $\mathrm{CO} / \mathrm{H}_{2} \mathrm{O}$ 为还原介质, 在温和条件下实现了纳米 $\mathrm{Au}$ 催化取代硝基或羰基化合物高效、高化学选择 性还原, 本文系统研究了包括传统铂族金属在内的各类高分散贵金属催化剂、反应温度、反应压力以及反应时间等对糠醛 转化率和糠醇选择性的影响. 通过优化催化剂制备和反应条件, 发现以 $\mathrm{CO} / \mathrm{H}_{2} \mathrm{O}$ 作为氢源, 在金红石单相 $\mathrm{TiO}_{2}$ 负载纳米 $\mathrm{Au}\left(\mathrm{Au} / \mathrm{TiO}_{2}-\mathrm{R}\right)$ 的催化作用下, 于 $90{ }^{\circ} \mathrm{C}, \mathrm{CO}$ 压力为 $4 \mathrm{MPa}$, 糠醛与 $\mathrm{Au}$ 的摩尔比为 200 的条件下反应 $4 \mathrm{~h}$ 即可实现糠醛至 
糠醇的定量转化. 研究表明, 上述过程中催化剂可多次循环使用; 反应温度或反应压力的增加均有利于反应进行, 且在糠 醛与纳米 $\mathrm{Au}$ 的摩尔比高达 2000 甚至 5000 时, 反应仍可完全进行到底. 尤其值得一提的是, 该催化体系对于反应原料中 含有相当杂质的非新鲜提纯的粗糠醛亦具有很好的耐受性, 甚至可直接以各种 $\mathrm{H}_{2} / \mathrm{CO}$ 比例的来源广泛的合成气为氢源, 实 现目标反应, 表明该体系是一种极具开发和应用潜力的糠醛转化制糠醇新技术.

关键词: 糠醛; 还原; 负载型金催化剂; 一氧化碳; 水相

收稿日期: 2016-04-14. 接受日期: 2016-05-10. 出版日期: 2016-10-05.

*通讯联系人. 电话: (021)55665287; 传真: (021)65643774; 电子信箱: yongcao@fudan.edu.cn

\#通讯联系人. 电话: (021)68462947; 传真: (021)68462283; 电子信箱: wangyd.sshy@sinopec.com

基金来源：国家自然科学基金 (21273044，21473035，91545108); 高等学校博士学科点专项科研基金 (2012007000011); SINOPEC(X514005); 上海市科学技术委员会资助项目 (08DZ2270500); 化学工程联合国家重点实验室开放课题 (SKL-ChE-15C02).

本文的英文电子版由Elsevier出版社在ScienceDirect上出版(http://www.sciencedirect.com/science/journal/18722067). 